\title{
A look at the $\mathrm{C} 3$ and $\mathrm{C} 5$ proteins in the Covid-19
}

\author{
Una mirada a las proteínas C3 y C5 en el Covid-19
}

Henry David Mosquera-Daza ${ }^{1 *}$

\begin{abstract}
The emergency caused by the new SARS-CoV-2 virus, which causes the Covid-19 disease, has triggered a global pandemic. One of the most characteristic factors of the SARS-CoV-2 virus infection is the deregulated activation of the complement system, especially by proteins $\mathrm{C} 3$ and $\mathrm{C} 5$. These proteins trigger initiation and maintenance reactions of inadequate biological activities, besides uncontrolled immune responses by immune cells, especially neutrophils. They generate various pathologies such as acute stroke, heart attack, coagulopathies, multiorgan failure, inflammation, immunothrombinosis, heart failure, acute kidney injury, acute injuries in the lung area, thrombotic microangiopathy, pneumonia, and dysfunctional immune responses. Because of the crucial role played by proteins $\mathrm{C} 3$ and $\mathrm{C} 5$ in the infection by the SARS-COV- 2 virus, new complement system inhibition treatments have emerged as a possible first line of defense against the worst symptoms developed during Covid-19 disease. This article will review, in a general way, the role of C3 and $\mathrm{C} 5$ proteins and the treatments aimed at the inhibition of these proteins during the SARS-CoV- 2 infection.
\end{abstract}

Keywords: C3, C5, Complement, Inhibition, SARS-CoV-2

\section{Resumen}

La emergencia causada por el nuevo virus SARS-CoV-2, causante de la enfermedad Covid-19, ha desencadenado una pandemia a nivel global. Uno de los factores más característicos de la infección por el virus SARS-CoV-2, es la activación desregulada del sistema del complemento, especialmente por parte las proteínas C3 y C5. Estas proteínas desencadenan reacciones de iniciación y de mantenimiento de actividades biológicas inadecuadas, además de respuestas inmunitarias descontroladas por parte de las células inmunes, en especial los neutrófilos. Generan diversas patologías como: accidente cerebrovascular agudo, ataque al corazón, coagulopatías, falla multiorgánica, inflamación, inmunotrombinosis, insuficiencia cardíaca, lesión renal aguda, lesiones agudas en el área pulmonar, microangiopatía trombótica, neumonía, y respuestas inmunes disfuncionales. Debido al rol crucial que presentan las proteínas C3 y C5 en la infección por el virus SARS-COV-2, nuevos tratamientos de inhibición del sistema del complemento han emergido como una posible primera línea de defensa contra los peores síntomas desarrollados durante la enfermedad Covid-19. En este artículo se revisará de manera general, el rol de las proteínas C3 y C5 y los tratamientos dirigidos a la inhibición de estas mismas proteínas durante la infección por SARS-CoV-2.

Palabras clave: C3, C5, Complemento, Inhibición, SARS-CoV-2

\footnotetext{
1. Universidad de La Salle, Department of Basic Sciences, Bogotá, Colombia.

* Author for correspondence: <hmosquera38@unisalle.edu.co>
} 


\section{INTRODUCTION}

In December 2019, China informed the World Health Organization (WHO) about the spread of a new pathogen in the Chinese city of Wuhan, this pathogen was named Severe Acute Respiratory Syndrome Coronavirus 2 (SARS-CoV-2) (Abd El-Aziz and Stockand, 2020), causing the Covid-19 disease. The Covid-19 disease has been categorized as a global pandemic. The SARS-CoV-2 virus spreads by droplets of mucus and saliva (Rothan and Byrareddy, 2020). Once a person is infected with the SARSCoV-2 virus, the spike homotrimer glycoprotein of the virus connects to the integral membrane protein ACE2 of human cells (Lan et al., 2020; Rothan and Byrareddy, 2020), many of these receptors are found in the lung epithelium layer, making them one of the main sites of infection of the SARS-CoV-2 virus (Connors and Levy, 2020).

In the SARS-CoV-2 infection, most patients do not develop symptoms (Risitano et al., 2020). However, for patients who develop severe symptoms, it is due to the abnormal production of cytokines by infected cells (Conti et al., 2020; Hirano and Murakami, 2020; Rothan and Byrareddy, 2020), and the deregulated activation of the complement system, especially by the C3 and C5 proteins (Fletcher-Sandersjöö and Bellander, 2020; Java et al., 2020; Jodele and Köhl, 2020; Mastaglio et al., 2020; Mastellos et al., 2020; Ramlall et al., 2020; Risitano et al., 2020; Stahel and Barnum, 2020). This deregulated activation of the complement system and cytokines induces a frenzy in immune cells, which generates injuries in the body that cause serious symptoms in the infection by SARS-CoV-2 (Risitano et al., 2020), such as a pneumonia (Jiang et al., 2020; Lescure et al., 2020; Naicker et al., 2020; Rothan and Byrareddy, 2020), acute lung injury (ALI) (Fu et al., 2020; Polycarpou et al., 2020), extreme inflammation (Carvelli et al., 2020; Didangelos, 2020; Fu et al., 2020; Noris et al., 2020), thrombotic microangiopathy, (FletcherSandersjöö and Bellander, 2020; Middleton et al., 2020; Ramlall et al., 2020; Skendros et al., 2020), coagulopathies (Connors and Levy, 2020), acute kidney injury (Fanelli et al., 2020), multi-organ failure, (Devaux et al., 2020; Mastellos et al., 2020; Noris et al., 2020), heart failure (Devaux et al., 2020), immunothrombinosis (Mastaglio et al., 2020b; Mastellos et al., 2020), acute stroke (Conway and Pryzdial, 2020; Yeboah et al., 2020), and dysfunctional immune responses in the attempt to control the disease (Tay et al., 2020).

The partial inhibition of the complement system is a possible treatment to regulate the uncontrolled immune reactions of the host and the severe symptoms caused by it (Java et al., 2020; Polycarpou et al., 2020), reducing the number of patients with severe symptoms and therefore the number of patients in intensive care (figure 1).

\section{MATERIALS AND METHODS}

In this manuscript, sixty articles were reviewed. Thirty articles correspond to the role and treatments of the complement system in Covid-19, eight articles correspond to pathologies related to the complement system (outside of Covid-19), as well as the symptoms associated to them, seven articles correspond to the characteristics, origin and role of the complement system in human health, six articles correspond to the treatments designed for the complement system during Covid-19, five articles correspond to the immunological factors associated, and four articles correspond to the epidemiology, and etiology of the virus (figure 2).

\section{An overview of the complement system}

The complement system is a group of more than 40 proteins (Merle et al., 2015) that evolved over 700 million years ago (Meng et al., 2012) which are closely related to the immune system since they are key in the opsonization of pathogens. The activation of the complement system is vital to the control of viruses, fungi, bacteria, and other pathogens, this activation triggers the opsonization of the pathogens and the elimination of them (Merle et al., 2015; Sarma and Ward, 2011); the activation is sequential: a catalytic cascade is produced through the generation of complex enzymes and proteins, in one step an enzyme or protein of this cascade can generate many active molecules for the next step in the activation of the complement system (Merle et al., 2015). 


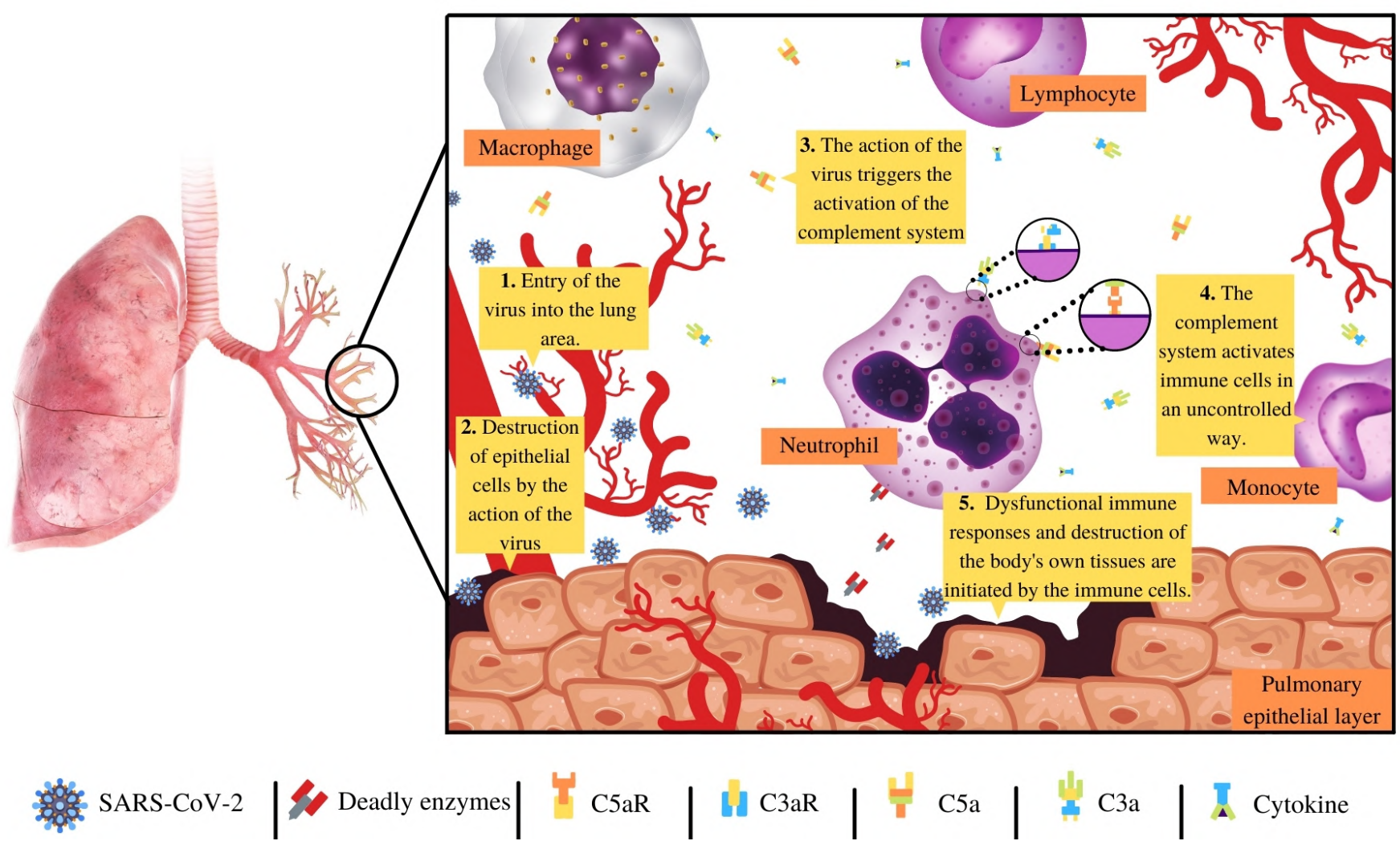

Figure 1. Once a person is infected with the SARS-CoV-2, in stage one (1) the virus arrives in the lung area, get into the cells of the epithelial layer of the lung with the purpose of reproducing, and produces mores viruses, (2) in this process many cells of the epithelial layer of lung died, which triggers the immune response. In step three and four $(3,4)$ the complement system and other immune complexes like cytokines are activated, which leads to a cascade of immunological reactions, activating and polarizing a multitude of immune cells in an uncontrolled way by the complement system and cytokines, especially neutrophils. Involving that in step five (5), the uncontrolled activation and overwhelming of the complement system and other immune complexes, triggers them in a frenzy of the immune cells producing a multitude of the collateral damage of the epithelial tissue of the lung, and other tissues of many organs leading to many of the worst symptoms producing during SARS-CoV-2 infection.

The activation of the complement system can be divided in three pathways: the classical pathway, the lectin pathway, and the alternative pathway (Merle et al., 2015a; Merle et al., 2015b; Sarma and Ward, 2011). The classical pathway involves the activation of the complement system by an antibody IgG, IgM or pentraxins (PTX) (Haapasalo and Meri, 2019), which can recognize pathogens and eliminate them by binding directly to C1q complement protein (Merle et al., 2015; Sarma and Ward, 2011). The lectin activation pathway involves the activation of the complement system by a lectin molecule MASP-
2 , which recognizes mannose present in pathogenic organisms that enter the body (Merle et al., 2015; Sarma and Ward, 2011). The alternative pathway is highly volatile; it is activated in many ways, either through the activation of carbohydrates, proteins, or lipids from foreign bodies, which are mainly triggered by the hydrolysis of the thioester bond present in the C3 protein, dividing it into the protein subdomains C3a and C3b (Merle et al., 2015; Sarma and Ward, 2011). 


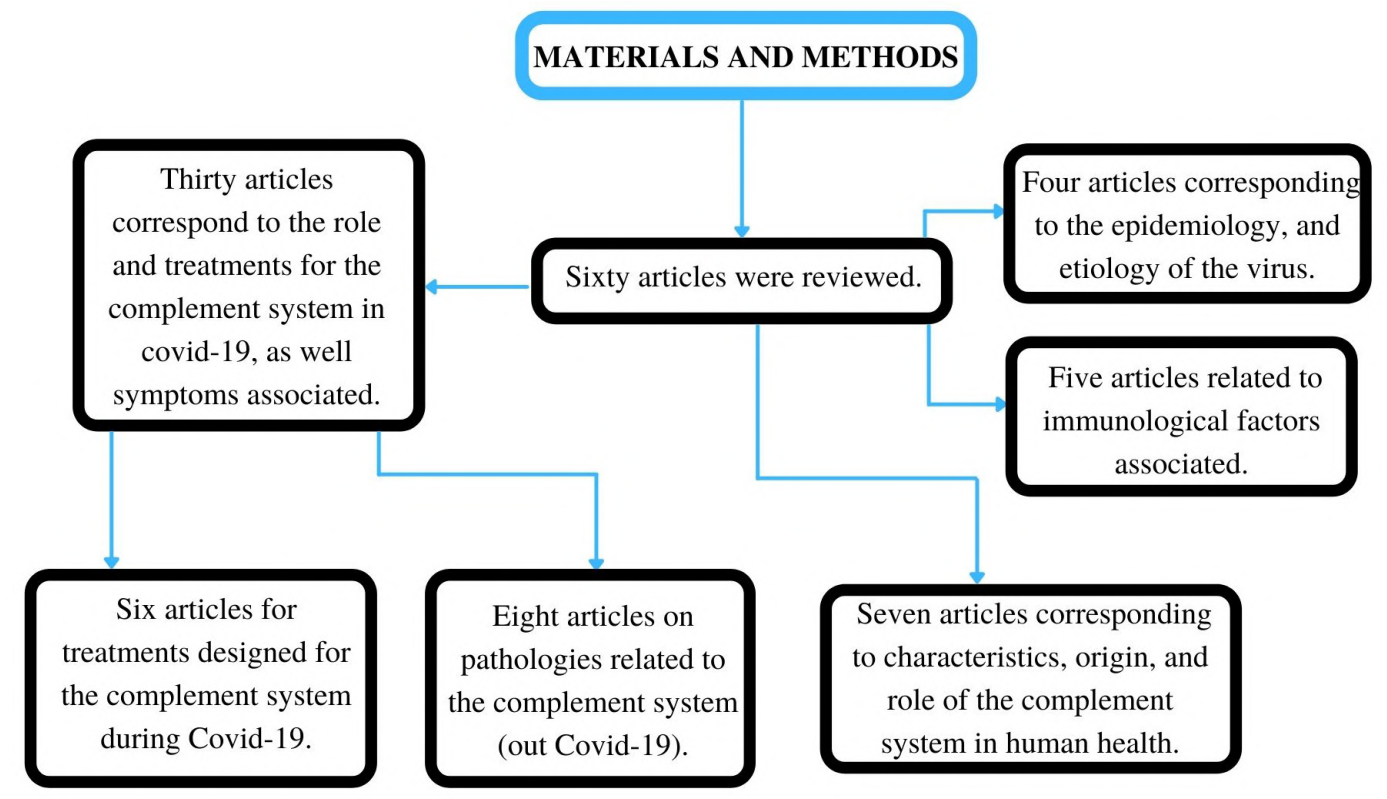

Figure 2. Chart of materials and methods used to the elaboration of the review.

\section{The complement system, $\mathrm{C} 3, \mathrm{C} 5$, and the SARS- CoV-2}

In Covid-19, many parts of the activation of the complement system interact during infection. For example, studies have shown that the natural antibodies IgM anti-A, and anti-B activate the complement system early by the classical pathway, reducing the viral load, and hence avoiding the generation of serious symptoms, such as pneumonia (Java et al., 2020).

It is also evidenced that the nucleoprotein dimer synthesized by the SARS-CoV-2, activates the mannanbinding lectin serine protease 2 (MASP-2) (Gao et al., 2020; Java et al., 2020), the trigger molecule of the lectin pathway. The deregulated activation of the complement system is one of the causes of the frenzy of immune cells (Fletcher-Sandersjöö and Bellander, 2020; Java et al., 2020; Mastellos et al., 2020). Cytokines produce the worst injuries and symptoms in the SARS-CoV-2 infection (Conti et al., 2020; Hirano and Murakami, 2020; Ramlall et al., 2020; Rothan and Byrareddy, 2020).

It is worth noting that the frenzy of immune cells generated by excessive activation of the complement system is not an isolated factor during Covid-19 (Didangelos, 2020; Java et al., 2020; Mastaglio et al., 2020a). Many diseases, especially autoimmune diseases have the same triggering factor (Sadik et al., 2018; Ricklin et al., 2016), for example amyotrophic lateral sclerosis (Carpanini et al., 2019), in individuals with obesity and insulin resistance (Moreno-Navarrete and Fernández- Real, 2019), immune disorders and complications in the placenta which cause problems during pregnancy in women with antiphospholipid syndrome (Chighizola et al., 2020).

The overwhelming presence of neutrophils and immune cells in the lung area is due to several factors; notably, the chemoattractant action carried out by cytokines (Java et al., 2020; Rothan and Byrareddy, 2020), chemokines that attract neutrophils, leukocytes, and others immune cells (Allegra et al., 2020; Didangelos, 2020).

The complement system plays a critical role in the chemotaxis, especially proteins C3, C5, which break into two protein subdomains, the important effector proteins C3a, C5a (Jodele and Köhl, 2020), C3b and C5b (Merle et al., 2015a; Merle et al., 2015b; 
Sarma and Ward, 2011). C3a and C5a are anaphylatoxins whose job is to attract immune cells to the site of infection, inducing pro-inflammatory reactions (Ajona et al., 2019), activating neutrophils, monocytes, (Carvelli et al., 2020), Blymphoblasts, and the activation and polarization of lymphocytes (Shivshankar et al., 2020).

Specifically, C3a is a chemotactic protein, vital to innate immune responses (Kwak et al., 2018) and adaptive responses (Chen et al., 2018). The interactions of C3a with its $\mathrm{C} 3 \mathrm{aR}$ receptor, measured by associated G proteins (Chen et al., 2018; Laumonnier et al., 2020), can generate various biological reactions, ranging from the opsonization of pathogens to the formation of tumors and pathogenesis of various diseases such as Covid-19 (Chauhan et al., 2020; Kwak et al., 2018).

During Covid-19, the excessive presence of C3a generates the activation and polarization of lymphocytes through the vascular endothelium during an immune response (Shivshankar et al., 2020), an excessive inflammatory response (Ajona et al., 2019; FletcherSandersjöö and Bellander, 2020), and the deregulated action of neutrophils and immune cells, aggravating the conditions of acute lung injury (Carvelli et al., 2020; Didangelos, 2020; Mastaglio et al., 2020; Mastellos et al., 2020b; Risitano et al., 2020; Shivshankar et al., 2020). In mice infected with SARS$\mathrm{CoV}$, the complement system, especially the C3a protein, shows a high expression one day after virus infection, aggravating the pathogenesis of the SARSCoV virus (Gralinski et al., 2018).

On the other hand, C5a anaphylatoxin is a neutrophil-attracting chemokine (Didangelos, 2020). This protein has a critical role in the generation of thrombosis in Covid-19 due to its interactions with neutrophils (Fletcher-Sandersjöö and Bellander, 2020; Mastellos et al., 2020; Middleton et al., 2020; Ramlall et al., 2020; Skendros et al., 2020). It also induces them to fight with the pathogen, producing collateral damage (Bardoel et al., 2014). In addition, the interactions of $\mathrm{C} 5 \mathrm{a}$ and its receptor C5aR1 have a role in the initiation and maintenance of the inflammatory responses of neutrophils and monocytes (Carvelli et al., 2020).
$\mathrm{C} 3 \mathrm{~b}$, a promoter of the formation of $\mathrm{C} 3 \mathrm{bBb}$ (van den Bos et al., 2019), has the job of amplification of catalytic reactions of the complement system (van den Bos et al., 2019), producing more components of the complement system and increasing the autoimmune reactions (Mastaglio et al., 2020a; Risitano et al., 2020).

C5b is a first part of the membrane attack complex (MAC) (Paredes et al., 2018), and in the SARSCoV-2 infection it has been found to be related to purpuric skin lesions, thrombogenic vasculopathy, with deposits in the epithelial tissue of the skin (Java et al., 2020; Magro et al., 2020). In addition, the virus increases the number of proteins $\mathrm{C} 4 \mathrm{~d}$ and C5b-9, in the interalveolar septa and the cutaneous microvasculature (Java et al., 2020; Magro et al., 2020). There is also evidence of the presence of C5b-9 in tubular epithelial cells of the kidney (Java et al., 2020).

These molecules that interact with neutrophils and other immune cells produce the worst symptoms: acute injuries in the lung area (ALI), pneumonia, extreme inflammation, thrombotic microangiopathy, acute kidney injury, multi-organ failure, heart failure, immunothrombinosis, and dysfunctional immune responses (Carvelli et al., 2020; Didangelos, 2020; Mastaglio et al., 2020a; Risitano et al., 2020; Shivshankar et al., 2020).

\section{The C3 and C5 target in treatment for Covid-19}

Following the knowledge of the deregulated activation of the complement system, and the activity of C3 and C5 proteins in SARS-CoV-2 virus infection, new treatments destined for the complement system emerged as part of a possible first line of defense against the worst symptoms caused by Covid-19 disease, with anti-C5a treatments being promising (Campbell and Kahwash, 2020; Java et al., 2020; Risitano et al., 2020). Anti-C5 treatment shows an immediate improvement through the reaction of inflation and an increase in pulmonary oxygenation (Risitano et al., 2020). Anti-C5a inhibitors have already been previously used in various pathologies (Risitano et al., 2020), showing positive results in the recovery of patients. Such is the case of the delayed 
hemolytic transfusion reactions in sickle cell anemia (Floch et al., 2020), fulminant hemolytic anemia by cryoglutinins (Makishima et al., 2019), paroxysmal nocturnal hemoglobinuria (Stern and Connell, 2019) and ischemia caused by acute renal injury (Zilberman-Itskovich et al., 2019).

In SARS-CoV-2 infection, the treatment commonly used as anti-C5a is the monoclonal antibody Eculizumab (Java et al., 2020; Laurence et al., 2020; Stahel and Barnum, 2020). This monoclonal antibody has been accepted by most patients with Covid-19 (Java et al., 2020), showing good results and noticeable improvement (Laurence et al., 2020; Mastellos et al., 2020; Risitano et al., 2020). However, the Eculizumab antibody is not the only anti-C5a antibody. New anti-C5a drugs such as the IFX-1 antibody (Vlaar et al., 2020), and Ruxolitinib in combination with Eculizumab (Giudice et al., 2020), show favorable and promising results in the inhibition of the complement system and anaphylatoxin C5a (Vlaar et al., 2020).

Anti-C5a treatments are not the only ones in the first line of defense against Covid-19. Anti-C3 treatments such as the AMY-101 compstatin inhibitor (Mastaglio et al., 2020b; Mastellos et al., 2020; Risitano et al., 2020) present favorable results in the control of hyper inflammation, thrombotic microangiopathy, immunothrombinosis caused by SARSCoV-2 infection, (Mastaglio et al., 2020b; Mastellos et al., 2020; Risitano et al., 2020). However, the search for new treatments targeting the complement system, such as the inactivation of the MASP-2 molecule (Java et al., 2020), vialectins, are promising options for the control of the serious symptoms caused by SARS-CoV-2 infection which leads to the Covid-19 disease.

\section{ACKNOWLEDGEMENTS}

The author expresses his special thanks to Professor Yenny Yolanda Lozano Jiménez, for all the support and the time dedicated.

\section{CONFLICT OF INTEREST}

The author declares not to have any conflict of interests.

\section{REFERENCES}

Abd El-Aziz, T. M., \& Stockand, J. D. (2020). Recent progress and challenges in drug development against COVID-19 coronavirus (SARS-CoV-2) - an update on the status. Infection, Genetics and Evolution, 83, Article 104327. DOI:10.1016/j.meegid.2020.104327

Ajona, D., Ortiz-Espinosa, S., \& Pio, R. (2019). Complement anaphylatoxins C3a and C5a: Emerging roles in cancer progression and treatment. Seminars in Cell and Developmental Biology, 85, 153-163. DOI:10.1016/j.semcdb.2017.11.023

Allegra, A., Di Gioacchino, M., Tonacci, A., Musolino, C., \& Gangemi, S. (2020). Immunopathology of SARSCoV-2 infection: Immune cells and mediators, prognostic factors, and immune-therapeutic implications. International Journal of Molecular Sciences, 21(13), 1-19. DOI:10.3390/ijms21134782

Bardoel, B. W., Kenny, E. F., Sollberger, G., \& Zychlinsky, A. (2014). The balancing act of neutrophils. Cell Host and Microbe, 15(5), 526-536. DOI:10.1016/j.chom.2014.04.011

Campbell, C. M., \& Kahwash, R. (2020). Will Complement inhibition be the new target in treating COVID-19-related systemic thrombosis? Circulation, 141(22), 1739-1741. DOI:10.1161/CIRCULATIONAHA.120.047419

Carpanini, S. M., Torvell, M., \& Morgan, B. P. (2019). Therapeutic inhibition of the complement system in diseases of the central nervous system. Frontiers in Immunology, 10, Article 362. DOI:10.3389/fimmu.2019.00362

Carvelli, J., Demaria, O., Vély, F., Batista, L., Chouaki Benmansour, N., Fares, J., Carpentier, S., Thibult, M. L., Morel, A., Remark, R., André, P., Represa, A., Piperoglou, C., Assante Miranda, L., Baron, W., Belaid, N., Caillet, C., Caraguel, F., Carrette, B., Vivier, E. (2020). Association of COVID-19 inflammation with activation of the C5a-C5aR1 axis. Nature, 588(7836), 146-150. DOI:10.1038/s41586-020-2600-6

Chauhan, A. J., Wiffen, L. J., \& Brown, T. P. (2020). COVID19: A collision of complement, coagulation and inflammatory pathways. Journal of Thrombosis and Haemostasis, 18(9), 2110-2117. DOI:10.1111/jth.14981

Chen, X. H., Ruan, C. C., Ge, Q., Ma, Y., Xu, J. Z., Zhang, Z. B., Lin, J. R., Chen, D. R., Zhu, D. L., \& Gao, P. J. (2018). Deficiency of complement C3a and C5a receptors prevents Angiotensin II-induced hypertension via regulatory T cells. Circulation Research, 122(7), 970983. DOI:10.1161/CIRCRESAHA.117.312153

Chighizola, C. B., Lonati, P. A., Trespidi, L., Meroni, P. L., \& Tedesco, F. (2020). The complement system in the pathophysiology of pregnancy and in systemic autoimmune rheumatic diseases during pregnancy. Frontiers in Immunology, 11, Article 2084. 
DOI:10.3389/fimmu.2020.02084

Connors, J. M., \& Levy, J. H. (2020). COVID-19 and its implications for thrombosis and anticoagulation. Blood, 135 (23), 2033-2040. DOI:10.1182/BLOOD.2020006000

Conti, P., Ronconi, G., Caraffa, A., Gallenga, C. E., Ross, R., Frydas, I., \& Kritas, S. K. (2020). Induction of pro-inflammatory cytokines (IL-1 and IL-6) and lung inflammation by Coronavirus-19 (COVI-19 or SARSCoV-2): anti-inflammatory strategies. Journal of biological regulators and homeostatic agents, 34(2), 327-331. DOI:10.23812/CONTI-E

Conway, E. M., \& Pryzdial, E. L. G. (2020). Is the COVID19 thrombotic catastrophe complement-connected? Journal of Thrombosis and Haemostasis, 18(11), 2812-2822. DOI:10.1111/jth.15050

Devaux, C. A., Rolain, J. M., \& Raoult, D. (2020). ACE2 receptor polymorphism: Susceptibility to SARS-CoV-2, hypertension, multi-organ failure, and COVID-19 disease outcome. Journal of Microbiology, Immunology and Infection, 53(3), 425-435. DOI:10.1016/j.jmii.2020.04.015

Didangelos, A. (2020). COVID-19 Hyperinflammation: What about Neutrophils? MSphere, 5(3), e00367-20. DOI:10.1128/msphere.00367-20

Fanelli, V., Fiorentino, M., Cantaluppi, V., Gesualdo, L., Stallone, G., Ronco, C., \& Castellano, G. (2020). Acute kidney injury in SARS-CoV-2 infected patients. Critical Care, 24 (1), 155. DOI:10.1186/s13054-020-02872-z

Fletcher-Sandersjöö, A., \& Bellander, B. M. (2020). Is COVID-19 associated thrombosis caused by overactivation of the complement cascade? A literature review. Thrombosis Research, 194, 36-41. DOI:10.1016/j.thromres.2020.06.027

Floch, A., Morel, A., Zanchetta-Balint, F., CordonnierJourdin, C., Allali, S., Grall, M., Ithier, G., Carpentier, B., Pakdaman, S., Merle, J. C., Goulabchand, R., Khalifeh, T., Berceanu, A., Helmer, C., ChantalatAuger, C., Frémeaux-Bacchi, V., Michel, M., de Montalembert, M., Mekontso-Dessap, A., Pirenne, F., Habibi, A., \& Bartolucci, P. (2020). Anti-C5 antibody treatment for delayed hemolytic transfusion reactions in sickle cell disease. Haematologica, 105(11), 2694-2697. DOI:10.3324/haematol.2020.253856

Fu, Y., Cheng, Y., \& Wu, Y. (2020). Understanding SARSCoV-2-Mediated Inflammatory Responses: From Mechanisms to Potential Therapeutic Tools. Virologica Sinica, 35(3), 266-271. DOI:10.1007/s12250-020-00207-4

Gao, T., Hu, M., Zhang, X., Li, H., Zhu, L., Liu, H., Dong, Q., Zhang, Z., Wang, Z., Hu, Y., Fu, Y., Jin, Y., Li, K., Zhao, S., Xiao, Y., Luo, S., Li, L., Zhao, L., Liu, J. Zhao, H., Liu, Y., Yang, W., Peng, J., Chen, X., Li, P., Liu, Y., Xie, Y., Song, J., Zhang, L., Ma, Q., Bian, X., Chen, W., Liu, X., Mao, Q., \& Cao, C. (2020). Highly pathogenic coronavirus N protein aggravates lung injury by MASP-2-mediated complement over-activation. MedRxiv, 2020.03.29.20041962. DOI:10.1101/2020.03.29.20041962

Giudice, V., Pagliano, P., Vatrella, A., Masullo, A., Poto, S., Polverino, B. M., Gammaldi, R., Maglio, A., Sellitto, C., Vitale, C., Serio, B., Cuffa, B., Borrelli, A., Vecchione, C., Filippelli, A., \& Selleri, C. (2020). Combination of Rux- olitinib and Eculizumab for Treatment of Severe SARSCoV-2-Related Acute Respiratory Distress Syndrome: A Controlled Study. Frontiers in Pharmacology, 11, Article 857. DOI:10.3389/fphar.2020.00857

Gralinski, L. E., Sheahan, T. P., Morrison, T. E., Menachery, V. D., Jensen, K., Leist, S. R., Whitmore, A., Heise, M. T., \& Baric, R. S. (2018). Complement activation contributes to severe acute respiratory syndrome coronavirus pathogenesis. MBio, 9(5), e01753-18. DOI: $10.1128 / \mathrm{mBio} .01753-18$

Haapasalo, K., \& Meri, S. (2019). Regulation of the Complement System by Pentraxins. Frontiers in immunology, 10, Article 1750. DOI:10.3389/fimmu.2019.01750

Hirano, T., \& Murakami, M. (2020). COVID-19: A New Virus, but a Familiar Receptor and Cytokine Release Syndrome. Immunity, 52(5), 731-733. DOI:10.1016/j.immuni.2020.04.003

Java, A., Apicelli, A. J., Kathryn Liszewski, M., ColerReilly, A., Atkinson, J. P., Kim, A. H. J., \& Kulkarni, H. S. (2020). The complement system in COVID-19: Friend and foe? JCI Insight, 5(15). DOI:10.1172/jci.insight.140711

Jiang, S., Du, L., \& Shi, Z. (2020). An emerging coronavirus causing pneumonia outbreak in Wuhan, China: calling for developing therapeutic and prophylactic strategies. Emerging Microbes and Infections, 9(1), 275-277. DOI:10.1080/22221751.2020.1723441

Jodele, S., \& Köhl, J. (2021). Tackling COVID-19 infection through complement-targeted immunotherapy. British Journal of Pharmacology, 178(14), 2832-2848. DOI:10.1111/bph.15187

Kwak, J. W., Laskowski, J., Li, H. Y., McSharry, M. V., Sippel, T. R., Bullock, B. L., Johnson, A. M., Poczobutt, J. M., Neuwelt, A. J., Malkoski, S. P., Weiser-Evans, M. C., Lambris, J. D., Clambey, E. T., Thurman, J. M., \& Nemenoff, R. A. (2018). Complement activation via a C3a receptor pathway alters CD4+ $\mathrm{T}$ lymphocytes and mediates lung cancer progression. Cancer Research, 78(1), 143-156. DOI:10.1158/0008-5472.CAN-17-0240

Lan, J., Ge, J., Yu, J., Shan, S., Zhou, H., Fan, S., Zhang, Q., Shi, X., Wang, Q., Zhang, L., \& Wang, X. (2020). Structure of the SARS-CoV-2 spike receptor-binding domain bound to the ACE2 receptor. Nature, 581(7807), 215-220. DOI:10.1038/s41586-020-2180-5

Laumonnier, Y., Karsten, C. M., Köhl, G., \& Köhl, J. (2020). Characterization of anaphylatoxin receptor expression and $\mathrm{C} 3 \mathrm{a} / \mathrm{C} 5 \mathrm{a}$ functions in anaphylatoxin receptor reporter mice. Current Protocols in Immunology, 130(1), e100. DOI:10.1002/cpim.100

Laurence, J., Mulvey, J. J., Seshadri, M., Racanelli, A., Harp, J., Schenck, E. J., Zappetti, D., Horn, E. M., \& Magro, C. M. (2020). Anti-complement C5 therapy with eculizumab in three cases of critical COVID-19. Clinical Immunology, 219, Article 108555. DOI:10.1016/j.clim.2020.108555

Lescure, F. X., Bouadma, L., Nguyen, D., Parisey, M., Wicky, P. H., Behillil, S., Gaymard, A., Bouscambert-Duchamp, M., Donati, F., Le Hingrat, Q., Enouf, V., HouhouFidouh, N., Valette, M., Mailles, A., Lucet, J. C., Mentre, F., Duval, X., Descamps, D., Malvy, D., Yazdanpanah, Y. (2020). Clinical and virological data of the first cases 
of COVID-19 in Europe: a case series. The Lancet Infectious Diseases, 20(6), 697-706. DOI:10.1016/S14733099(20)30200-0

Magro, C., Mulvey, J. J., Berlin, D., Nuovo, G., Salvatore, S., Harp, J., Baxter-Stoltzfus, A., \& Laurence, J. (2020). Complement associated microvascular injury and thrombosis in the pathogenesis of severe COVID-19 infection: A report of five cases. Translational Research, 220, 1-13. DOI:10.1016/j.trsl.2020.04.007

Makishima, K., Obara, N., Ishitsuka, K., Sukegawa, S., Suma, S., Kiyoki, Y., Baba, N., Sakamoto, T., Kato, T., Kusakabe, M., Nishikii, H., Kurita, N., Yokoyama, Y., SakataYanagimoto, M., Hasegawa, Y., \& Chiba, S. (2019). High efficacy of eculizumab treatment for fulminant hemolytic anemia in primary cold agglutinin disease. Annals of Hematology, 98(4), 1031-1032. DOI:10.1007/s00277-0183521-4

Mastaglio, S., Ruggeri, A., Risitano, A. M., Angelillo, P., Yancopoulou, D., Mastellos, D. C., Huber-Lang, M., Piemontese, S., Assanelli, A., Garlanda, C., Lambris, J. D., \& Ciceri, F. (2020). The first case of COVID-19 treated with the complement C3 inhibitor AMY-101. Clinical Immunology, 215, Article 108450. DOI:10.1016/j.clim.2020.108450

Mastellos, D. C., Pires da Silva, B. G. P., Fonseca, B. A. L., Fonseca, N. P., Auxiliadora-Martins, M., Mastaglio, S., Ruggeri, A., Sironi, M., Radermacher, P., Chrysanthopoulou, A., Skendros, P., Ritis, K., Manfra, I., Iacobelli, S., Huber-Lang, M., Nilsson, B., Yancopoulou, D., Connolly, E. S., Garlanda, C., Ciceri, F., Risitano, A. M., Calado, R. T., \& Lambris, J. D. (2020). Complement C3 vs C5 inhibition in severe COVID-19: Early clinical findings reveal differential biological efficacy. Clinical Immunology, 220, 108598. DOI:10.1016/j.clim.2020.108598

Meng, F., Sun, Y., Liu, X., Wang, J., Xu, T., \& Wang, R. (2012). Analysis of c3 suggests three periods of positive selection events and different evolutionary patterns between fish and mammals. PLoS ONE, 7(5). DOI:10.1371/journal.pone.0037489

Merle, N. S., Church, S. E., Fremeaux-Bacchi, V., \& Roumenina, L. T. (2015). Complement system part I - molecular mechanisms of activation and regulation. Frontiers in Immunology, 6, Article 262. DOI:10.3389/fimmu.2015.00262

Merle, N. S., Noe, R., Halbwachs-Mecarelli, L., FremeauxBacchi, V., \& Roumenina, L. T. (2015). Complement system part II: Role in immunity. Frontiers in Immunology, 6, Article 257. DOI:10.3389/fimmu.2015.00257

Middleton, E. A., He, X. Y., Denorme, F., Campbell, R. A., Ng, D., Salvatore, S. P., Mostyka, M., Baxter-Stoltzfus, A., Borczuk, A. C., Loda, M., Cody, M. J., Manne, B. K., Portier, I., Harris, E. S., Petrey, A. C., Beswick, E. J., Caulin, A. F., Iovino, A., Abegglen, L. M., Weyrich, A. S., Rondina, M. T., Egeblad, M., Schiffman, J. D., \& Yost, C. C. (2020). Neutrophil extracellular traps contribute to immunothrombosis in COVID-19 acute respiratory distress syndrome. Blood, 136(10), 1169-1179. DOI:10.1182/blood.2020007008

Moreno-Navarrete, J. M., \& Fernández-Real, J. M. (2019). The complement system is dysfunctional in metabolic disease: Evidences in plasma and adipose tissue from obese and insulin resistant subjects. Seminars in Cell and Developmental Biology, 85, 164-172. DOI:10.1016/j.semcdb.2017.10.025

Naicker, S., Yang, C. W., Hwang, S. J., Liu, B. C., Chen, J. H., \& Jha, V. (2020). The Novel Coronavirus 2019 epidemic and kidneys. Kidney International, 97(5), 824828. DOI:10.1016/j.kint.2020.03.001

Noris, M., Benigni, A., \& Remuzzi, G. (2020). The case of complement activation in COVID-19 multiorgan impact. Kidney International, 98(2), 314-322. DOI:10.1016/j.kint.2020.05.013

Paredes, R. M., Reyna, S., Vernon, P., Tadaki, D. K., Dallelucca, J. J., \& Sheppard, F. (2018). Generation of complement molecular complex C5b-9 (C5b-9) in response to poly-traumatic hemorrhagic shock and evaluation of C5 cleavage inhibitors in non-human primates. International Immunopharmacology, 54, 221-225. DOI:10.1016/j.intimp.2017.10.033

Polycarpou, A., Howard, M., Farrar, C. A., Greenlaw, R., Fanelli, G., Wallis, R., Klavinskis, L. S., \& Sacks, S. (2020). Rationale for targeting complement in COVID19. EMBO Molecular Medicine, 12(8). DOI:10.15252/emmm.202012642

Ramlall, V., Thangaraj, P. M., Meydan, C., Foox, J., Butler, D., Kim, J., May, B., De Freitas, J. K., Glicksberg, B. S., Mason, C. E., Tatonetti, N. P., \& Shapira, S. D. (2020). Immune complement and coagulation dysfunction in adverse outcomes of SARS-CoV-2 infection. $\mathrm{Na}$ ture Medicine, 26(10), 1609-1615. DOI:10.1038/s41591020-1021-2

Ricklin, D., Reis, E. S., \& Lambris, J. D. (2016). Complement in disease: a defence system turning offensive. Nature Reviews Nephrology, 12(7), 383-401. DOI:10.1038/nrneph.2016.70

Risitano, A. M., Mastellos, D. C., Huber-Lang, M., Yancopoulou, D., Garlanda, C., Ciceri, F., \& Lambris, J. D. (2020). Complement as a target in COVID19? Nature Reviews Immunology, 20(6), 343-344. DOI:10.1038/s41577-020-0320-7

Rothan, H. A., \& Byrareddy, S. N. (2020). The epidemiology and pathogenesis of coronavirus disease (COVID-19) outbreak. Journal of Autoimmunity, 109, Article 102433. DOI:10.1016/j.jaut.2020.102433

Sadik, C. D., Miyabe, Y., Sezin, T., \& Luster, A. D. (2018). The critical role of C5a as an initiator of neutrophil-mediated autoimmune inflammation of the joint and skin. Seminars in Immunology, 37, 21-29. DOI:10.1016/j.smim.2018.03.002

Sarma, J. V., \& Ward, P. A. (2011). The complement system. Cell and Tissue Research, 343(1), 227-235. DOI:10.1007/s00441-010-1034-0

Shivshankar, P., Li, Y. D., Mueller-Ortiz, S. L., \& Wetsel, R. A. (2020). In response to complement anaphylatoxin peptides C3a and C5a, human vascular endothelial cells migrate and mediate the activation of B-cells and polarization of T-cells. FASEB Journal, 34(6), 7540-7560. DOI:10.1096/fj.201902397R

Skendros, P., Mitsios, A., Chrysanthopoulou, A., Mastellos, D. C., Metallidis, S., Rafailidis, P., Ntinopoulou, M., 
Sertaridou, E., Tsironidou, V., Tsigalou, C., Tektonidou, M., Konstantinidis, T., Papagoras, C., Mitroulis, I., Germanidis, G., Lambris, J. D., \& Ritis, K. (2020). Complement and tissue factor-enriched neutrophil extracellular traps are key drivers in COVID-19 immunothrombosis. Journal of Clinical Investigation, 130(11), 6151-6157. DOI:10.1172/JCI141374

Stahel, P. F., \& Barnum, S. R. (2020). Complement Inhibition in Coronavirus Disease (COVID)-19: A Neglected Therapeutic Option. Frontiers in Immunology, 11, Article 1661. DOI:10.3389/fimmu.2020.01661

Stern, R. M., \& Connell, N. T. (2019). Ravulizumab: a novel C5 inhibitor for the treatment of paroxysmal nocturnal hemoglobinuria. Therapeutic Advances in Hematology, 10, 204062071987472. DOI:10.1177/2040620719874728

Tay, M. Z., Poh, C. M., Rénia, L., MacAry, P. A., \& Ng, L. F. P. (2020). The trinity of COVID-19: immunity, inflammation and intervention. Nature Reviews Immunology, 20(6), 363-374. DOI:10.1038/s41577-020-0311-8

van den Bos, R. M., Pearce, N. M., Granneman, J., Brondijk, T. H. C., \& Gros, P. (2019). Insights into enhanced complement activation by structures of properdin and its complex with the C-terminal domain of C3b. Frontiers in Immunology, 10, Article 2097. DOI:10.3389/fimmu.2019.02097

Vlaar, A. P. J., de Bruin, S., Busch, M., Timmermans, S. A. M. E. G., van Zeggeren, I. E., Koning, R., ter Horst, L., Bulle, E. B., van Baarle, F. E. H. P., van de Poll, M. C. G., Kemper, E. M., van der Horst, I. C. C., Schultz, M. J., Horn, J., Paulus, F., Bos, L. D., Wiersinga, W. J., Witzenrath, M., Rueckinger, S., Pilz, K., Brouwer, M. C., Guo, R-F., Heunks, L., van Paassen, P., Riedemann, N. C., van de Beek, D. (2020). Anti-C5a antibody IFX-1 (vilobelimab) treatment versus best supportive care for patients with severe COVID-19 (PANAMO): an exploratory, open-label, phase 2 randomised controlled trial. The Lancet Rheumatology, 2(12), e764-e773. DOI:10.1016/S2665-9913(20)30341-6

Yeboah, K., Edgell, R., Conway, J., \& Alshekhlee, A. (2021). Interventional stroke management in a patient with COVID-19. Neurology: Clinical Practice, 11(2), e199e201. DOI:10.1212/cpj.0000000000000884

Zilberman-Itskovich, S., Abu-Hamad, R., Stark, M., \& Efrati, S. (2019). Effect of anti-C5 antibody on recuperation from ischemia/reperfusion-induced acute kidney injury. Renal Failure, 41(1), 967-975. DOI:10.1080/0886022X.2019.1677248 